Est Ag 36 (2001) 347-376

\title{
Sloterdijk versus Habermas. Humanismo, patria y metafísica
}

\section{Introducción}

Dado el bloqueo actual de las prescripciones positivistas y los graves problemas suscitados por la economía global, era necesario revisar el sentido del hombre y de la vida a fin de buscar nuevos horizontes de futuro. Para cumplir esta tarea habíamos comenzado a releer la Carta sobre el humanismo de Heidegger. Al comenzar esta reflexión, nos sorprende la famosa polémica Sloterdijk-Habermas.

La conferencia del primero: Normas para el Parque Hümano. Una respuesta a la Carta sobre el humanismo de Heidegger ${ }^{1}$, ha levantado, en Alemania, un considerable escándalo, con duras acusaciones entre su autor y el entorno de Habermas. Así se ha mencionado el fascismo, el nazismo y otras basuras, y ha propiciado un fuerte contraataque de Sloterdijk que se defendido con una dura respuesta que lleva por título: La teoría crítica ha muerto.

Trataremos de ver las cosas por su orden y ofrecer algunas sugerencias acerca de la Carta sobre el humanismo, puesta de nuevo de moda por Sloterdijk. De la potencialidad filosófica de Sloterdijk ya habíamos avisado en La Aventura posmoderna, publicado, en esta misma revista.

Allí decíamos lo siguiente: «Para Peter Sloterdijk: "El concepto realidad es el concepto que más falsamente se utiliza" $»^{2}$. La paranoia de bloques armados se confunde con la realidad; nos encontramos ante un cinismo militar que

1. P. SLOTERDIJK, Normas para el parque humano. Una respuesta a la Carta sobre el humanismo de Heidegger, trad. T. Rocha Barco, Siruela, Madrid 2000. En adelante NPH. Cf. también C. DREYMUELLER, Un claro en el bosque y El nacimiento del centauro, ABC Cultural 4.11.2000, 9; M. BARROS CASARES, El pensador en escena. Peter Sloterdijk, El Cultural 20.12.2000, 27.

2. P. SLOTERDIJK, Crítica de la razón cínica, Taurus, Madrid 1989, II 24. En adelante CRC. 
se une al cinismo comercial, político, económico y religioso: «El modo y manera cómo dos o más magnitudes de poder se vuelven locas mutuamente, en una interacción imaginaria, suministra al hombre de nuestra época su modelo de realidad. Quien se adapta a la sociedad de hoy, tal y como ésta es, en última instancia se adaptará a este realismo paranoico»3.

«Así, el realismo actual no es otra cosa que la fuerza misma del sistema, la camisa de fuerza que el interés brutal y el poder violento impone a la sociedad normal».

«Así es como el socialismo se identificaba con la realidad bajo el nombre de "socialismo real"; y, del mismo modo, el nazismo reclamaba de una masa de acero y cemento, la realidad dura y todopoderosa, el bunker de su propia realidad. También aquí la quintaesencia del endurecerse heroico es decir, ahí, "orgullo", un yo-bloque que se constituye en una máquina en sí misma heroicamente racional. Los manuales de enseñanza del nacional socialismo sabían apreciarlo» ${ }^{4}$. En esta dinámica, «la metafísica de la fuerza se impone y se identifica la violencia y el ser; así el ser es el señor y es lo que se impone sin más: la razón de la fuerza»5.

Para romper este fatum es preciso meditar, a fin de que la ignorancia no siga en primera fila. Lo dice así Sloterdijk: «Me da la impresión de que la sociedad actual, en medio de la terrible crisis de sus clases políticas, no puede hacer nada mejor que darse una pausa par la reflexión sobre cuestiones fundamentales. Hay que ganar tiempo para un debate constitucional que proceda a una indagación de (sobre) la forma del mundo. Probablemente, el generalizado menear la cabeza en alusión a las deficiencias del personal político oculta un descontento global que aún no ha tomado forma: apostaría directamente a que se trata de los estados aurorales de una toma de conciencia de alcance mundial sobre insuficiencias antropológicas. Pues lo que salta a la vista de los intranquilos contemporáneos con respecto a tantos políticos -el hecho de que raramente estén a la altura de los retos globales- igualmente rige, con más razón, para los que no son políticos. Se debería examinar si la censura crónica a la clase política no será la proyección de un malestar general de la cultura mundial, sólo que cristalizado ante la prominencia política» 6 .

3. CRC II 23.

4. CRC II 29.

5. D. NATAL, La aventura postmoderna. Est. Agust. 27 (1992) 62.

6. P. SLOTERDIJK, En el mismo barco. Ensayo sobre la hiperpolítica, trad. M. Fontán del Junco, Siruela, Madrid 2000, 2a , 71-72. En adelante EB. 
Ahora bien los políticos tendrán que tener paciencia, porque ante la aldea global surge siempre "una paranoia étnica y vecinal" cuyo nombre más decente es el de "postmodernidad". Se necesita "una terapia política de las psicosis de las formas nacionales del mundo", que propicie la "convivencia" que lleva a un mundo humano frente a lo monstruoso, de lo inhumano y la dispersión de las hordas para que la convivencia humana no desemboque «en un campo de batalla y el territorio del Estado en la tumba del pueblo»? Habrá pues que recordar que las comunas acaban en totalitarismo y la desatención a los pueblos en "psicopatológicos callejones sin salida" restos de "épocas agrarias" . Hoy la política es el arte de la "pertenencia mutua" y la democracia actual se olvida, con frecuencia, de este pequeño detalle que lleva a la insularidad a la deriva y al más triste individualismo, al fatuo experimentalismo y a la "pandilla sin sustancia". «En este "individualismo de apartamento" de las grandes ciudades postmodernas, la insularidad llega a convertirse en la definición misma del individuo (...) El socialismo se ha hecho realidad en forma de asocialismo» 8 . Así no hay formación del hombre ni futuro de humanidad sino puro "nihilismo" donde hasta la productividad se convierte en destructiva.

Ante tanta inestabilidad se pide todo a los políticos, que se ven ante una apuesta "con muchas pretensiones, para la que no hay precedentes" puesto que deben evitar que las "patologías de la pertenencia se vuelvan epidémicas" y, ademas, suscitar, entre tanto individualista, "la capacidad de convivir", a fin de poder "reducir los enormes agujeros existentes entre la forma global del mundo" y las pasiones locales.

Se piden hombres ejemplares en las artes de convivencia: «Ahora se exigen conciencias sólidamente establecidas sobre el abismo de la paradoja del género humano. Profesión: político. Domicilio principal: la complejidad. Programa: convivir con aquellos con los que convivir resulta difícil. Moral: trabajo de filigranas en retos pretenciosos. Pasión: tener relación con lo irrelacionable. Historia: autorreclutamiento por convicción, que se transforma en iniciativa. Tales "políticos" tienen que entenderse a sí mismos primeramente como atletas de un nuevo tipo: atletas del mundo sincronizado, almas de alta capacidad en el tema de la coexistencia»?.

7. EB 90.

8. EB 96-97.

9. EB 73-74. 


\section{Un pueblo es su Metafísica}

No deja de llamar la atención que un escrito tan cercano a Carta sobre el humanismo, de Heidegger, haya creado una polémica tan notable. Supuesto que Heidegger es un brujo metafísico y las metafísicas, según se suele decir, no miran la realidad ni se refieren a los problemas concretos ni candentes de la vida ni deberían quemar a nadie.

Estos son tópicos al uso de quién no sabe en verdad, de qué va la Metafísica. De hecho en Carta sobre el Humanismo, Heidegger, discute lo que entendemos por humanismos, por hombre, por patria, por historia, por Europa e incluso por el nacionalismo. De este último dice así: «Todo nacionalismo es metafísicamente un antropologismo, y, en cuanto tal, subjetivismo. El nacionalismo no se supera con el internacionalismo, sino que se extiende y se eleva a sistema»10. Además, venerando a Hölderlin, asegura Heidegger que la patria «no la busca él, en modo alguno, en un egoísmo de su pueblo»11. Para terminar afirmando que la patria hay que buscarla en «la cercanía del ser»12.

Así pues, como diría muy bien, con una gran intuición, más valiosa que todo su libro, el, en otro tiempo, debelador de Ortega: Un pueblo es su metafísica, o en sus términos literales: «Un pueblo es lo que es su Metafísica»13. Por lo demás, asegura Heidegger: «la historia, es la historia del ser»14. Como diría Sloterdijk: «De hecho, el homo politicus y el homo metaphysicus históricamente se dan juntos; los buscadores del Estado y los buscadores de Dios son evolutivamente, gemelos. $Y$ es que junto a la grandeza demográfica y social la grandeza cosmológica y metafísica también exige sus derechos. Pero ocurre que en cuanto lo grande en absoluto da que pensar, tienen que aparecer interpretaciones del mundo y doctrinas del ser que expliquen cómo está constituido el orden del todo, cuales son sus desajustes y de qué curas se dispone para ellos» ${ }^{15}$. Eso hizo la filosofía griega, y lo volvió a plantear Heidegger, en su Carta sobre el humanismo, como veremos después.

10. M. HEIDEGGER, Carta sobre el humanismo, Taurus, Madrid 1966, 2a 4 40. En adelante $\mathrm{CH}$.

11. $\mathrm{CH} 36$.

12. $\mathrm{CH} 37$.

13. J. IRIARTE, Ortega y Gasset, su persona y su doctrina, Razón y Fe, Madrid 1942, 5. 14. «Die Geschichte ist Geschichte des Seins»: M. HEIDEGGER, Gesamtausgabe. I. Abteilung: Veröffentlichte. Schriften 1910-1976. Band 6.2. Nietzsche II. Vittorio Klostermann, Frankfurt am Main 1997, 20. En adelante HN.

15. EB 38-39. 
Ahora bien, la negativa, en redondo, a considerar crítica alguna a la izquierda o a la derecha, para emplear los términos convencionales, tanto de la Nueva Filosofía como de la Postmodernidad como de la Etología ha llevado a que los problemas, atascados muchos años, hayan explotado ahora, como un todo y de repente. De la Nueva Filosofía, a pesar del importante grupo de autores que aglutinaba, llegó a decirse que ni era nueva ni era filosofía. Decir esto, por ejemplo, ante Los Maestros pensadores de Glucksmann, claramente se veía que era una barbaridad.

En España era difícil encontrar textos de estos autores y había que buscarlos en Francia y leerlos, según cada uno entendía, como si estuviéramos de nuevo en tiempos de la censura puesto que oficialmente nada se sabía del tema. La Barbarie con rostro humano, de B. Henri-Levy, una excelente crítica a la ideología de la técnica y de paso al marxismo, fue editada en Venezuela, en un español complicado que nos recordaba la curiosa traducción argentina de Love Story. Y los Maestros pensadores de Glucksmann, un libro bastante difícil, fue editado en España y no era fácil de adquirir. Lo demás era silencio, hasta la publicación del escrito de Ch. Jambet y G.Lardreau, El Angel. Ontología de la revolución. Una mezcla de cristianismo y maoísmo que cruzó bien las fronteras quizá apoyado en su título angelical. Y es que la Nueva Filosofía hacía una crítica contundente del marxismo, del capitalismo y de la técnica, que nadie quería aceptar ${ }^{16}$.

De la Postmodernidad, que volvía a insistir sobre la violencia de la Modernidad y en la crítica de los dos sistemas clásicos, muy pocos querían oir nada. Oficialmente no existió. A pesar de la claridad de Lyotard y del contundente análisis de Lipovetsky en La era del vacío, todo era tachado de pura blandenguería y de retorno de los brujos. Sólo el prestigio de G. Vattimo y el desarrollo del tema en literatura y arte, en América y Europa, hizo que la idea se impusiera ${ }^{17}$.

En la Etología, desde los tiempos de Lorenz todo parecía biologismo. ¿Acaso querían volvernos al mundo de los animales?. Pero la Sociobiología anglosajona logró imponerse poco a poco, y entonces se vio la necesidad de comenzar a plantearse las normas del parque humano, que ahora suscitan de nuevo tan oscuro temor, ya que la simple moral no ha conseguido evitar grandes desastres humanos y crueldades sin cuento. Los temas del territorio, las

16. D. NATAL, Ante la ética de la fuerza o el tema de nuestro tiempo, en Est. Agust. 15 (1980) 199-224.

17. He resumido el tema en: La Aventura posmoderna, en Est. Agust. 27 (1992) 53-122; 29 (1994) 97-153; 30 (1995) 437-490. 
patrias y los nacionalismos son ejemplos, por desgracia tan contundentes, tan clásicos y actuales que dejan muy pocas dudas ${ }^{18}$.

Por otra parte, no es muy rara la impresión de que siempre que ocurre algo en bioética inmediatamente se toma una postura negativa, asustadiza, sin ton ni son, que Sloterdijk rechaza y denuncia. Basta recordar los primeros transplantes de corazón del Dr. Barnard, para citar un caso bien conocido, y que hoy nos resulta un poco esperpéntico.

\section{La Normas del Parque Humano}

\subsection{Una famosa polémica}

Sloterdijk pronuncia, por primera vez, su conferencia: Normas para el parque humano. Una respuesta a la Carta sobre el Humanismo de Heidegger, el 15 de junio de 1997 en Basilea, dentro de unas jornadas sobre el humanismo en las que habían hablado muchos profesores. Allí no ha pasado nada, ni hubo alarma alguna. Por eso, el autor entiende a los que piensan que debía haber desarrollado más algunos temas o haber explicitado algunos tópicos, pero no acepta que se haya malentendido el tema central de su discurso: «el peligroso final del humanismo literario como utopía de la formación humana mediante el escrito y mediante la lectura, que educa al hombre en la paciencia, la contención del juicio y la actitud de oídos abiertos»19.

En julio de 1999 repite la conferencia en las Jornadas de Elmau, sobre Heidegger y Lévinas, en presencia de teólogos y filósofos de varios países, sin que hubiera objeción alguna. Pero unos periodistas, presentes en las Jornadas, escriben un informe "denunciatorio". «El resto de la historia tiene como resultado el debate Sloterdijk (o el escándalo Sloterdijk-Habermas, como se denomina en Francia)»20. El escándalo se refiere a algunos interrogantes del autor sobre bioética, moral y formación humana, que algunos periodistas convirtieron en "prescripciones". Su conferencia fue publicada también en francés, y su referencia en Internet fue visitada 60.000 veces en quince días.

18. D. NATAL, El instinto territorial y su orientación, en Est. Agust. 18 (1983) 343-370. 19. NPH 89.

20. NPH 90-91. Cf. también R. DE WECK, Kulturkampf (Günter Grass, Jürgen Habermas y sus antagonistas) (Die Zeit 7.10.1999), en Revista de Occidente 228 (2000) 108112; J. L. MOLINUEVO, ¿Fin del Humanismo? Presentación, Ib., 75-79. 
El autor piensa que ha sido un poco ingenuo por no tener en cuenta la capacidad de la prensa para descontextualizar las cosas y crear "masivas psicosis simplificadoras". «Pero es una debilidad conocida del escritor no dejarse orientar en su escritura por los malentendedores de costumbre o de oficio»21.

De haber escuchado a Heidegger, habría oído este consejo: «¿No debemos más bien soportar por algún tiempo aún las ineludibles malinterpretaciones y dejarlas gastarse lentamente, interpretaciones a las cuales está expuesto hasta ahora el camino del pensar en el elemento del ser y tiempo? Estas malinterpretaciones son las naturales interpretaciones de revés de lo leído o de lo sólo rementado en lo que se cree saber ya antes de leer. Todas ellas muestran la misma configuración y el mismo cimiento». -«Porque se habla contra el "humanismo" se teme una defensa de lo in-humano y una glorificación de la bárbara brutalidad» 22 .

¿Tan raro había sido lo que había dicho Sloterdijk en Normas para el parque humano?. Antes de entrar en el texto conviene saber que nuestro autor ha denunciado el letargo actual de la filosofía alemana y su rigidez académica, su histeria antitecnológica y su incapacidad para responder a los nuevos problemas de la biotécnica ${ }^{23}$. Además, según Sloterdijk, ha habido una campaña desatada por el entorno de Habermas, con la complicidad de cierta prensa, que han frivolizado el tema.

Por otra parte, en Alemania, bastante gente está ya harta del fantasma del pasado y la culpa interminable. Como lo diría Sloterdijk: «La generación de los hijos culpables abandona la escena paulatinamente y deja paso a una generación de nietos que, en muchos aspectos, es mucho más desinhibida, y puede vivir por primera vez en Alemania como si fuera un país normal. Este debate podría ser parte de la despedida de una anormalidad cultivada durante demasiado tiempo» 24 .

De ahí que ya en 1986 se hizo famosa "la disputa de los historiadores" sobre el holocausto. En 1993, B. Strauss escribe contra la culpabilización de toda la sociedad alemana por los hechos del pasado. En 1996, Martín Walser, en la línea de Strauss, se enfrenta a Habermas y sus actos públicos por "su forma de instrumentalizar la vergüenza alemana".

21. NPH 88.

22. CH 46.

23. NPH. Prólogo de T. Rocha Barco, 9.

24. S. GAECHTER, "Peter Sloterdijk: "Soy un monstruo sagrado"», Entrevista (Die Weltwoche 16.11.1999), en Rev. de Occidente 288 (2000) 116. 
Hasta ahora la disputa era siempre del pasado. Pero Sloterdijk, con su discurso, ha suscitado «una discusión profunda, científica, política y en parte también filosófica y teológica sobre el ser humano y sobre lo que puede y debe ser de él» 25 .

\section{2. Normas para el parque humano}

Sloterdijk piensa que los libros, como decía el poeta Jean Paul, "son voluminosas cartas para los amigos". Cree, además, un poco raro que un tema como el filosófico haya durado tantos siglos ganando amigos y enemigos. La recepción del humanismo clásico es un hecho extraordinario y una extraña acción in distans ${ }^{26}$.

$\mathrm{Al}$ principio los aludidos forman grupos reducidos porque son alfabetizados, saben leer y escribir, son los únicos humanistas. Pero desde hace dos siglos esa condición, de unos pocos, se extiende a los ciudadanos. El servicio militar impuesto y la lectura obligatoria «caracterizan la era burguesa clásica»27. Es la humanidad leída y armada.

Entre 1789 y 1945 los humanismos nacionales viven una época espléndida. «En sustancia, el humanismo burgués no era otra cosa que el pleno poder para imponer a la juventud los clásicos obligatorios y para declarar la validez universal de las lecturas nacionales» 28 . Pero hoy este humanismo parece estar acabado, pues con la radio y la tele las sociedades de hoy se construyen sobre un nuevo fundamento postliterario y posthumanístico. Por un momento hubo un renacer clásico, pero hoy el humanismo sólo es un recuerdo de la perpetua batalla por el hombre, de "una lucha entre tendencias embrutecedoras y amansadoras".

El mundo romano, con su pan y circo, y con sus brutos espectáculos nos muestra al hombre inhumano. En 1946, tras la cruel guerra mundial, Heidegger escribe su Carta sobre el humanismo. Sus enemigos le acusaron de elevarse a "las alturas de la contemplación mística", para rehabilitar su vida con un nuevo antihumanismo. Para Heidegger se trata de un nuevo humanismo pues ni el marxismo ni el cristianismo ni el existencialismo llegaron a «la

25. NPH. Prólogo,14-15.

26. NPH 23.

27. NPH 26.

28. NPH 27. 
radicalidad última de la pregunta por la esencia del hombre» ${ }^{29}$. Hasta hoy, todos los humanismos han mantenido al hombre, como animal racional, entre las especies animales y el ser zoológico aderezado con ciertos "aditivos espirituales".

Pero el hombre difiere metafísicamente de todos los animales porque es memoria del ser y el mejor "vecino del ser". La vida humana sólo recobra su esencia propia en el ámbito del ser cuando el hombre se convierte en un verdadero "pastor del ser". Así la misión del hombre consiste en «guardar al ser y corresponder al ser» ${ }^{30}$. El hombre no guarda el ser como un enfermo guarda cama sino como el pastor cuida el rebaño, en medio del claro del bosque, que es donde aparece el ser, y así guarda su propio mundo.

Ante el misterio del ser surge el misterio del hombre y las voces del silencio. Así, para Heidegger, el hombre, en su "recogimiento silencioso", deberá ser mucho más dócil y respetuoso que el manido humanista clásico. Entonces el ser sería el único autor de cartas y el escritor su amanuense. Pero no es fácil, ahora, aclarar cómo se podría constituir, hoy, una nueva sociedad de los "vecinos del ser". Desde luego no sería el "hombre fuerte" moderno, como se presentó a mediados del siglo XX en la "trágica titanomaquia" entre el bolchevismo, el fascismo y el americanismo. «Para Heidegger, el fascismo es la síntesis de humanismo y bestialidad, es decir, la paradójica coincidencia entre inhibición y desinhibición» 31 .

Los famosos juegos metafísicos de Heidegger, se pueden considerar pastoriles o desgraciada metafísica, pero plantean la pregunta fundamental que hoy debemos hacernos: ¿Qué le queda aún al hombre si fracasa el humanismo?. ¿Cómo llevar a razón a este gran conquistador que sólo piensa en dominar a los otros? ¿Quién y cómo educar al educador?

Según Sloterdijk, hay una historia natural de la apertura del hombre al ser en el mundo y una historia social de la formación del hombre en la que este se recoge "para corresponder al todo". Tal es la aventura de la hominización, relatada en la antropología, por la que el hombre convierte su medio animal en mundo. «Aún se podría ir más allá y designar al hombre como el ser que ha fracasado en su ser animal y en su mantenerse animal»32.

Con el sedentarismo aparecen los animales domésticos y el hombre, perdido su sentido de caminante, lucha con los otros hombres y se dedica a la

29. NPH 41.

30. NPH 45.

31. NPH 51.

32. NPH 55. 
acción, pierde la magnanimidad, su apertura a los demás y su apertura al ser y se empequeñece a sí mismo. Así el hombre ya no quiere a nadie sino que, como dice Nietzsche en Así habló Zaratustra: "la mayor parte únicamente son queridos". Para estos, la virtud consiste en hacerse "modesto y manso": «así han convertido al lobo en perro y al propio hombre en el mejor animal doméstico del hombre» 33 .

Entonces surge el "último hombre" que es el hombre domesticado por el humanista, profesor o cura, orientado a la "docilidad del animal doméstico". La lucha es entre los formadores de grandes hombres y de hombres empequeñecidos. Bajo la máscara de la escuela se hace domesticación. De ahí que hoy hemos de plantearnos de nuevo las técnicas sobre el hombre y los proyectos pastorales, la propia educación, que permita superar la candidez humanista. Los humanistas no quieren hablar de esto pero no queda más remedio, como es necesario hablar de la selección y el poder para que unos no sean sujetos y otros meros objetos de la obra del Estado. Así pues, es necesario «entrar activamente en el juego y formular un código de antropotécnicas»34.

Actualmente la batalla entre domesticadores y embrutecedores anuncia un claro fracaso, pues estamos, según parece, ante "una ola de desenfreno sin igual". Y como en el mundo antiguo el libro perdió la batalla ante el teatro, la escuela hoy la está perdiendo «ante los poderes educativos indirectos como la televisión, las películas violentas y otros medios de desinhibición, si no surge una nueva cultura de cultivo propio que mitigue esta violencia» 35 .

Cuestiones sobre "la reforma genética de las propiedades del género", la antropotecnia para planificar características humanas o el paso del fatalismo natal a la selección prenatal, son preguntas con las que el horizonte evolutivo, aún nebuloso e inseguro, "comienza a despejarse ante nosotros".

Una de las señas de identidad del hombre es la provocación de lo inaccesible que ha dejado huella profunda en el hombre, y esa es la filosofía. Pero en ella está también, como presenta Platón, el cuidado, la cría, y la formación del hombre. Este tratado político parece «una declaración de principios sobre las normas para la gestión empresarial de parques humanos» 36 .

Ahora bien, los hombres son seres que se cuidan a sí mismos, como también a su entorno, y de ahí su "dignidad". Y en todas partes el hombre debe

33. NPH 62.

34. NPH 71.

35. NPH 72, nota 18 .

36. NPH 75. 
formarse opinión "sobre el modo de regular su autosostenimiento". Unos quieren democracia y otros imponer tiranías. Los verdaderos guías del grupo humano sólo pueden encontrarse "si se descarta a los pastores de animales con cornamenta".

La formación del hombre se centra en "la crianza que se dedica a rebaños de animales bípedos, implumes, sin cuernos y de raza pura" (que no se mezcla con otras razas no humanas). Y puede ser violenta y tiránica o voluntaria. Aquella es incierta y engañosa. Esta, el verdadero arte de la política, se define como «el cuidado voluntario de rebaños... de seres voluntarios $(276 \mathrm{e}){ }^{37}$.

A partir de aquí, Platón, entra en el famoso tema de la reproducción humana en el Estado. Entonces cree que ha de ser dirigida por reyes y sabios capaces de entretejer las cualidades humanas, nobles y voluntarias, en bien del interés público, de modo que la fortaleza guerrera y la prudencia filosófico humana beneficien la sociedad con verdaderos ciudadanos "enérgicos y ecuánimes", unidos por "la concordia y la amistad".

Al lector, que conoce los "liceos humanistas" y la "eugenesia fascista" y "la era biotecnológica", «le es imposible ignorar el potencial explosivo de estos razonamientos» 38 . Platón busca un guardián adecuado para esta tarea "del pastoreo real" en un sucesor de Dios. Como los dioses se han retirado y los hombres deben cuidarse a sí mismos, el sabio queda como el más digno guardián y criador, pues él es quien tiene más vivo el recuerdo de las celestes visiones de lo mejor. «Sin el ideal del sabio, el cuidado por el hombre sería una pasión vana»39.

Pero hoy también faltan los sabios. Tenemos aún sus escritos pero sin motivos para leerlos. Así, están en las estanterías, como copias de un saber, en el que "hoy no conseguimos ya creer", enviadas por autores cuya amistad no sabemos. Así los libros son "objetos archivados", ya no son cartas de amigos ni presiden nuestra vida. Los mismos archiveros ya los ven poco, aunque a veces se encuentran con ciertos destellos, con algún claro del bosque, que todavía recuerda la tarea del humanista. Pero, desgraciadamente: «Entre los pocos que todavía se dan alguna vuelta por esos archivos, se impone la opinión de que nuestra vida es la confusa respuesta a preguntas que hemos olvidado dónde fueron planteadas» 40 .

37. NPH 79.

38. NPH 83

39. NPH 84.

40. NPH 85. 


\section{La Crítica de la Razón Cínica}

Sloterdijk se ha convertido en uno de los más definidos analistas de nuestro tiempo. Su obra es contundente. En sus escritos, el cinismo del capital y del marxismo oficial queda expuesto a plena luz como nunca se había hecho. Nunca hasta su Crítica de la razón cínica se había presentado una crítica tan demoledora al socialismo real, en nada inferior a su repudio del nazismo. Esto explicaría muchas cosas, pero sobre todo la polémica actual. Para la quincalla ideológica mediática sus escritos son una apisonadora. Esta obra le catapultó a la fama y se convirtió en un escrito muy leído y debatido en Alemania. Como dice Fernando Savater, se trata de «una de las obras más provechosas e inteligentes aparecidas en Alemania en los diez últimos años».

$\mathrm{Su}$ análisis de la situación actual es de una clarividencia enorme. Con él puede decirse que se termina una etapa y comienza realmente la filosofía postmoderna. Según escribíamos en 1992: «Como Peter Sloterdikj, ha sintetizado muy bien todo el problema, en su Crítica de la razón cínica, nosotros vamos a describir solamente algunos aspectos más decisivos e incisivos de la aventura postmoderna» 41 .

No es ahora el momento de presentar un resumen de esa obra ${ }^{42}$. Pero sí conviene recordar que entonces ya había advertido Sloterdijk que la política no puede convertirse en una algodicea que es como una nueva teodicea que justifica el dolor humano y la indiferencia social ante aquellos que lo sufren ${ }^{43}$. Creo que esto es lo que ha pasado, y de ahí el malestar actual que probablemente se extenderá hasta que las cosas cambien. Entonces todos, políticos y no políticos, nos habremos encontrado con la cruda «"realidad en lugar de una realidad" institucional y verbal» ${ }^{44}$.

Así surge una idea de política "capaz de dirigir su atención a la oculta ecología del dolor del mundo". La Ilustración y la Modernidad, verdaderas, pretendieron ser ya eso: «una entrada masiva de sujetos afligidos en el marco de nuevas realidades soportables, de alivios, derechos y enriquecimientos» 45 .

41. D. NATAL, La aventura, 56.

42. Para una aproximación a la filosofía del Sloterdijk, cf. G. CANO, Retrato del intelectual crítico como "centauro", en P. SLOTERDIJK, El pensador en escena. El materialismo de Nietzsche, Pre-textos, Valencia 2000, 7-16. En adelante PE.

43. «Algodicea alude a una interpretación metafísica que da sentido al dolor. En la modernidad aparece en lugar de la teodicea como su inversión» (CRC). Citado en PE 157.

44. PE 154.

45. PE 156. 
Así la política y la vida humana dejarían de ser un arte de prestidigitación, de violencia terminante y de "captura del poder", que en vez de resolver los problemas, del dolor humano, los espanta y los disuelve. Pero hoy es necesario asumir responsabildad en vez de buscar culpables.

\section{El Proyecto Zaratustra y La muerte de la Teoría Crítica}

\section{1. El Proyecto Zaratustra}

Pasado el verano del 99, en cuyo mes de julio Sloterdijk había dado, por segunda vez, su conferencia, de 1997, sobre las normas del parque humano, Thomas Assheuer, publica un artículo muy fuerte en contra de Sloterdijk, con un tono biologista, acusándole de eugenista y de defensor de una antropotecnia antidemocrática e indiscriminada. Le imputa también, Assheuer, querer sacar a la filosofía de la situación lunática y académica en que vive y prestigiarla con las ciencias ${ }^{46}$.

Así, Sloterdijk, trataría de superar la brutalidad humana actual con un nuevo proyecto reproductivo platónico que es un antiguo programa nietzscheano. También le acusa de dejar el proyecto en manos de unos sabios científicos, sin escrúpulos morales, que producirian una humanidad «de hombres más inteligentes y generosos» ${ }^{47}$. Además, cree que esto mismo alentaron J. Huxley, J. Lederberg y F. Crick. Assheuer afirma que la tecnología genética siempre ha actuado así, prometiendo el oro y el moro, pero llevando a todos la inseguridad, al terror de la irresponsabilidad y a la libertad de los mandarines.

También acusa, a Sloterdijk, de camuflar el proyecto con la metafísica del ser, y de pretender un hombre sometido y domesticado, conformista y vencido, sin principios ni religión.

El lector, de Sloterdijk, puede comprobar fácilmente cómo este autor rechaza con gran dureza toda interpretación eugenista de Nietzsche. Además para Sloterdijk, Heidegger no es ningún "dios lar" sino precisamente un nuevo humanismo que nos protege de los gurus del saber científico.

46. T. AssHEUER, El proyecto Zaratustra. El filósofo Peter Sloterdijk reclama una revisión genético-técnica de la humanidad (Die Zeit 2.11.1999), en Rev. de Occidente 228 (2000) 80-81.

47. T. ASSHEUER, El proyecto 85. 
Por otra parte, Sloterdijk para nada acepta las tesis eugenistas platónicas de la República en su sentido brutalmente antidemocrático. Y cuando admite que sin el ideal del sabio, «el cuidado del hombre por el hombre sería una pasión vana», afirma, con gran claridad, que como hicieron antes los dioses también se han "retirado" los sabios «dejándonos a solas con nuestra escasa sabiduría y nuestros conocimientos a medias» 48 . Y aunque tenemos sus escritos ya no tenemos fe en ellos y acaso ni los leemos.

Así, como dirá luego Sloterdijk, el lector se preguntará si Assheuer ha leído la famosa conferencia, o la Carta sobre el humanismo de Heidegger, a no ser que por leer se entienda la interpretación de la que habla Heidegger en su conocida carta que mira "de revés de lo leído o de lo sólo rementado en lo que se cree saber ya antes de leer". Así se cumpliría el dicho clásico que "lo que cada cual recibe, al modo del recipiente se recibe".

Por dos veces cita Assheuer la editorial Suhrkamp, como acusando a Sloterdijk de ser su fiel consejero. No sé si así se insinúa un conflicto de poder, en la cultura alemana, dado el gran significado de la citada editorial. No es difícil adivinar que habrá que afirmar que sí.

No es tampoco nada inocente que Assheuer nos recuerde que ya en 1991 Sloterdijk coqueteaba con estas nuevas ideas para acabar con el "hombre viejo" ${ }^{49}$. El lector comprenderá cuán reciente y caliente está aún, en esas fechas, la edición de la Crítica de la razón cínica con su ataque demoledor al socialismo real y por tanto a la vieja guardia, apodada el "hombre viejo".

En la misma línea se desempeña el siempre ponderado E. Tugendhat con la aseveración de que: No hay genes para la moral ${ }^{50}$. Desde luego nadie negará a su autor que su escrito vale por una conferencia de bioética. Pero Sloterdijk lo tiene muy claro: «Este no es mi tema. Nunca he tenido intención de intervenir en el debate de la tecnología genética. Hay otros que pueden hacerlo mejor. Lo único que digo es que tenemos que formular un código de antropotécnicas precisamente para que no pase lo que unos intérpretes histéricos están leyendo en mi texto» 51 .

En el escrito de Tugendhat, se acusa a Sloterdijk, una vez más, de deducir la moral del proceso de "crianza". Al menos, ya se admite que Nietzsche tenía una moral, aunque fuera rechazable, contra lo que siempre se había

48. NPH 4.

49. T. ASSHEUER, El proyecto 84.

50. E. TUGENDHAT, No hay genes para la moral (Die Zeit 23.11. 1999), en Rev. de Occidente 288 (2000)101-107.

51. P. GAECHTER, Peter Sloterdijk. Entrevista, 115-116. 
dicho. Al final, Tugendhat, afirma honestamente «que no ha comprendido cuál es el propósito del autor» 52 . Y tampoco sabe si nos ha ayudado en algo, aunque él cree que no.

Por otra parte, este autor se olvida, totalmente, de la Carta sobre el humanismo, de Heidegger, un elemento esencial en la propuesta de Sloterdijk, como si Heidegger fuera antihumanista o dijera que no hay ningún humanismo posible, y lo que es peor, cree que también Sloterdijk afirma lo mismo como puede verse al resumir la famosa conferencia en una:

« $1^{\text {a }}$ tesis: Heidegger tendría toda la razón al sostener que el humanismo ha tocado hoy a su fin, pero que se equivocaría al opinar que esto habría ocurrido en beneficio de la celebración del ser»53. De hecho, para Sloterdijk, el paso del mundo animal al mundo humano es un «éxodo (que) sólo produciría animales psicóticos si no tuviera lugar, al mismo tiempo que la salida al mundo, una entrada en eso que Heidegger llamó la casa del ser» ${ }^{54}$.

\section{2. La muerte de la Teoría Crítica}

La contundente respuesta de Sloterdijk no se hizo esperar nada. A la semana siguiente de publicarse el artículo de Assheuer, Sloterdijk responde con un escrito que contiene una carta a Assheuer y otra al propio Habermas. En la carta a Assheuer se pregunta Sloterdijk si la conferencia de la que habla ese autor es la misma que él ha dado: «Me encantaría comparar su ejemplar con el mío, para ver si estamos usando el mismo documento»55.

Pues, de hecho, se le atribuyen las teorías eugénicas de Nietzsche y de Platón que él rechaza, expresamente, con el calificativo de "conceptos histéricos e inadecuados". Y además, Sloterdijk distingue perfectamente: «las optimaciones legítimas de la medicina genética aplicadas a individuos y las biopolíticas ilegítimas aplicadas a los grupos» ${ }^{56}$.

El autor de Normas para el parque humano reconoce como bueno que la sociedad tenga sistemas de alarma para defenderse de ataques peligrosos y cree un hecho legítimo y positivo la crítica entre pensadores. Y esa misión,

52. E. TUGENDHAT, No hay genes 107.

53. E. TUGENDHAT, No hay genes, 101.

54. NPH 56.

55. P. SLOTERDIJK, La teoría crítica ha muerto (Die Zeit 9.11.99), en Rev. de Occidente 288 (2000) 90. En adelante TCM.

56. TCM 90. Cf. también P. SLOTERDIJK, El pensador en escena. ABC Cultural 4.11.2000, 7-8. 
hoy, la tiene la prensa, y la crítica de las ideologías. Sloterdijk acepta que es mejor que algunos se pasen, un poco, a que, por falta de crítica, se pierda o se dañe la sociedad. Pero también existe el derecho de alertar "contra los alertadores".

Recordando los gansos del Capitolio, que con su alarma salvaron, en otro tiempo, a Roma, este autor cree que Assheuer grazna demasiado, con un sentido autoreferencial muy fuerte, tipo pavo, y además "por encargo de un tercero". Assheuer alarma porque hay moros en la costa, pero Sloterdijk piensa que su crítico decide, por sí y ante sí, cuándo hay moros en la costa, y además se reserva el derecho de decidir lo qué sea un moro.

En este ambiente, para Sloterdijk, la opinión pública está evolucionando del alarmismo al "escandalismo". Entonces se pasa de la crítica auténtica a la «producción de excitaciones en un mercado de cuotas de atención que se ha quedado estrecho» ${ }^{57}$. Así, el escritor se convierte en un creador de publicidad o en un "escandalista, que estructuralmente es lo mismo". Y eso obliga a preguntarse a quién sirve el escritor.

Luego, Sloterdijk se vuelve hacia el dueño de la mano que "se tapa la boca", y que ha dado a otros la orden de ponerse en marcha y ha marcado su dirección. Se trata de J. Habermas. El es, el que ha susurrado a los críticos, en contra del "neoconservador". Por haber sido su profesor, y por respeto a sus escritos, que han formado a toda una generación, Sloterdijk se adelanta, a Habermas, para intentar volver a formas de entendimiento mutuo, "dialógicas y no difamatorias".

En primer lugar, le dice a Habermas que está al límite de la tolerancia, porque ha hablado de él «con mucha gente, nunca conmigo. En este oficio nuestro, basado en la argumentación, eso es ya sospechoso; en un teórico del diálogo democrático resulta incomprensible»58. Le acusa además de haber armado barullo y de haber llamado de Hamburgo a Jerusalén para presionar a sus amigos y "convertirlos a su error".

También le imputa el haber pasado copias pirata del texto de la conferencia, a alumnos y periodistas, contra todo uso académico. Además, ha reprochado a los participantes en el seminario de Elmau por no haber reaccionado contra la ahora famosa conferencia. También le acusa de que: «Ha encargado usted a un colaborador de Die Zeit, así como a un autor de Der Spiegel, que escribieran artículos alarmados en los que no debía aparecer su nombre. 
Primero tocó la corneta su discípulo Assheuer, luego fue Mohr quien cumplió con su obligación» 59 .

Poco después, le recuerda que, en este mundo, es un reyezuelo tirano o "soberano", quien puede tomar a otros como sus representantes, en persona, a su servicio, según explicaba el denostado C. Schmitt. Esa palabra, según Sloterdijk, «permite reconocer que usted sigue todavía esforzándose en desempeñar el papel de soberano de la producción alemana de discurso, incluso después de haber sido emérito» 60 .

Luego, pasa Sloterdijk a analizar ese episiodio desde la propia teoría de Habermas. Ahí, explica que a él se le toma como un objeto o cosa y no como un sujeto en igualdad de derechos con sus críticos. Además le recuerda a Habermas: «Ha recibido usted la herencia inhumana del estilo de pensamiento de la crítica de las ideologías, estilo que, ciertamente, no está mucho peor marcado en usted que en otros representantes de esta ya no tan respetable tradición»61. Pero cada cual tiene sus tradiciones, Habermas las basadas en los viejos tiempos, Sloterdijk en los nuevos.

Sloterdijk le recuerda además a Habermas que, aunque se le considere una cosa, podría ponerse nervioso y comenzar a hablar según una teoría bien conocida, en la misma Escuela de Frankfurt, y cumplir una vez más "la venganza de las cosas". El autor de la ya famosa conferencia, reivindica su derecho a declararse, al menos, res cogitans (cosa pensante), por lo que, en muy buena lógica, al menos "como autor y colega de editorial", se podía e "incluso se debía haber hablado con ella", dado que sólo vive a un día de correo de la casa de Habermas y a diez cifras de teléfono (incluidos los prefijos).

Sloterdijk responde con la contundencia de Heine, a quién nunca le gustaba la censura y menos la "que venía de colegas celosos". Estos ataques a Sloterdijk, le hacen más clarividente y le dan una mirada más objetiva para ver que hoy "la esencia de la teoría crítica se manifiesta en el crepúsculo". Y ahora, va a decir lo que ha visto: Con Th. Adorno, la Escuela de Frankfurt, sedujo a toda una generación con «una versión de izquierdas de círculo gnóstico al estilo del de Stefan George (...). En su versión más reciente (Habermas), era un jacobinismo latentemente sostenido, una versión socialliberal de la dictadura de la virtud (asociada con el arribismo periodístico y académico)» 62 .

59. TCM 94.

60. TCM 94-95.

61. TCM 95.

62. TCM 97. 
Para las democracias normales, ambas versiones, son un factor de riesgo, sobre todo la segunda, por ser más popular. Para las democracias no normales "ambos sistemas son justo lo correcto". Para Hegel, la esencia del terror consiste en que la sospecha se convierte en condena. Pero en el jacobinismo, "denunciar es ya lo mismo que liquidar". Esto, hoy día, es más peligroso porque los medios de comunicación de masas van mucho más rápido que en el tiempo de nazismo. Para Sloterdijk, en esas teclas es en las que está Habermas tocando.

Y estos comportamientos, ponen al descubierto cuál es su verdadera ética y lo que realmente significa, al final de la partida y en resumidas cuentas, para Habermas, la tan cacareada "coerción no coercitiva del mejor argumento". «Por tanto: que usted, el gran comunicador, el gran ético del discurso en Alemania, imbuido de su propio no-fascismo (está demostrado que su lema es: los fascistas son siempre los otros), emplee los medios del modo que se puede ver en este caso me da la ocasión de hacer notar cómo su máscara liberal cae cuando se produce el conflicto»63.

De la fuerza del argumento se pasa al argumento de la fuerza, la denuncia y la delación. Como diría Luhmann: "pasamos del discurso moral a la agitación ". Así, Habermas, pone al descubierto qué entiende por discutir, pensar, abordar problemas, "por opinión pública y por apertura".

Además, como siempre ha sido verdad el "calumnia que algo queda", todo ser humano atacado termina por ser el culpable. Quedan aún algunas dudas sobre a quién dañará más el debate, sobre todo si se desarrolla un metaescándalo «sobre el negocio de los fabricantes de escándalos en este país, sobre la industria alemana de la indignación, la decadencia de la crítica y las estrechas alianzas entre el jacobinismo liberal y el mundo del espectáculo» 64 .

Para Sloterdijk, la época de los hijos hipermoralistas de padres nacionalistas ha terminado. Ahora hay una generación más libre. Para ellos la sospecha y la acusación ya no significan tanto, y desprecian la neurosis jacobina de sus mayores de izquierdas, envueltos siempre en la niebla de la culpa de los tiempos de posguerra. Estos "que antes tenían el poder de determinar la mentalidad", ya no pueden imponerse y quieren colgarle la falta de libertad a todos sus descendientes. El tiempo de las conciencias excesivas, demasiado buenas y/o demasiado malas ha terminado.

63. TCM 98.

64. TCM 99. 
En fin: «La teoría crítica ha muerto este 2 de septiembre. La vieja dama gruñona estaba postrada en cama desde hace tiempo, y ahora se ha ido para siempre. Nos reuniremos junto a la tumba de una época para hacer balance, pero también para rememorar el final de una hipocresía. Pensar significa agradecer, había dicho Heidegger. Yo opino, más bien, que pensar significa respirar» 65 .

\section{La Carta sobre el Humanismo de Heidegger}

\subsection{El hombre, el ser y el lenguaje}

Mucho se ha discutido sobre si la filosofía de Heidegger era una antropología o más bien una metafísica. Las opiniones han estado muy encontradas y con frecuencia se ha dicho que era una antropología disfrazada de metafísica o que se trataba de una metafísica bajo capa antropológica ${ }^{66}$.

Una relectura de la Carta sobre el humanismo puede ofrecernos aclaraciones preciosas sobre este importante debate, tanto para la comprensión del hombre y el humanismo como para la justa valoración de la filosofía de Heidegger en el momento actual ${ }^{67}$.

Como es sabido, esta carta fue dirigida al profesor Jean Beaufret y, en ella, Heidegger hace muchas puntualizaciones sobre su filosofía, el humanismo europeo y el pensamiento de Sartre.

65. TCN

66. Kojève hace una lectura antropolugica de Ser y tiempo. «En su Carta sobre el "humanismo" (Brief über den "Humanismus") de 1946, Heidegger se distanció expresamente de su antropologización. Pero "ser ahí" (Dasein) puede leerse también como el ahí del ser mismo (Da-sein, Da des Seins selbst).Y el "ser-ahí" del hombre significa "ex-sistencia" (Ex-sistenz), un "exponerse" (Hinaus-stehen) a la verdad del Ser» (...) «Ahí se vislumbra un pensamiento que parte del Ser como un "claro" (Lichtung) que permite ofrecer espacio a la aparición y la demostración, del Ser como "acontecimiento" (Ereignis). Finalmente, existen también intentos de aceptar directamente la ontología de Heidegger, pasando de todas las interpretaciones antropológicos: así en Jean Beaufret (...), destinatario de la carta sobre el humanismo, y en los discípulos de éste» (B. WALDENFELS, De Husserl a Derrida. Introducción a la fenomenología, Paidós, Barcelona 1997, 62.66). De otra parte, Heideger no aceptó nunca el lenguaje de la metafísica clásica. Para él, al lenguaje le faltan los conceptos apropiados para expresar el "ser". «Se atrevió a pensar "ser" (Sein) aunque se debería escribir "Seyn" (ser)- como verbo» (G. GADAMER, Mito y Razón, Paidós, Barcelona 1997, 114-115).

67. Cf. A. LEYTE, Historia de la Carta sobre el "Humanismo ", ABC Cultural 4.11.2000, 10-11. L. F. MORENO ClAROS, De nuevo el mago, Ib., 11. I. REGUERA, ¿Cómo volver a dar sentido a la palabra humanismo?. Ib., 12-13. 
Comienza Heidegger por señalar que nos falta claridad sobre la esencia del obrar y sobre la acción humana, pues con frecuencia confundimos acción con efectividad. Pero, para Heidegger, actuar significa llevar algo a "la plenitud de su esencia", no se trata del mero desplegar las posibilidades de las cosas, sino de alcanzar su realidad más profunda, porque lo que «ante todo "es", es el ser» 68 .

Del mismo modo, el puro pensar trae a plenitud «la relación del ser con la esencia del hombre. No efectúa ni impulsa esta relación»69, porque el pensar aporta al ser del hombre "lo que le es entregado a él mismo por el ser". Pues «en el pensar el ser viene al lenguaje. El lenguaje es la casa del ser. En su vivienda mora el hombre» 70 . Poetas y pensadores vigilan esta morada, y su vigilia se produce en la patencia misma del ser ${ }^{71}$.

El pensador se deja envolver por el ser para decir su verdad. «El pensar obra en cuanto piensa»72. Y este pensar es el compromiso con "la verdad del ser". En cambio, la acción "descansa en el ser" pero apunta al ente.

«La historia del ser lleva y determina toda condition et situation humaine» ${ }^{73}$. La experiencia del ser supera toda Lógica y toda Gramática. Y en la vivencia de su plenitud "debemos liberarnos de la interpretación técnica del pensar". El pensar, tanto en Platón como en Aristóteles, es un arte "al servicio del quehacer y del hacer", pero el verdadero pensar no es "práctico".

Cuando el pensar acontece como una mera teoría técnica del obrar, la filosofía se encuentra en la «penosa situación de justificar ante las "ciencias" su existencia» 74 . Entonces se identifica con las ciencias por miedo a perder

68. CH 7. Del mismo modo, para Heidegger, la esencia del nihilismo es la eliminación del ser: «Das Wesende des Nihilismus ist das Ausbleiben des Seins als solchen» (HN 347). La verdad profunda del ser falta en la idea de ente. Por eso la historia occidental es nihilista, oculta el misterio del ser, y así le da buena muerte sin apenas darse cuenta: «Pensado a partir del destino del ser, el nihil del término nihilismo significa que no pasa nada con el ser. El ser no llega a la luz de su propia esencia. En la manifestación de lo ente como tal, el propio ser se queda fuera. La verdad del ser no aparece, permanece olvidada» (M. HEIDEGGER, Caminos del bosque, Alianza, Madrid 1995, 238. En adelante CB).

69. $\mathrm{CH} 7$.

70. $\mathrm{CH} 7$.

71. Todo pensador depende "de la llamada del ser" (CB 332). Esa es su libertad y su mayor riqueza. Pero el ser no es actualidad ni cruda objetividad sino, como dice Ortega, la realidad de la realidad. Según Rilke: «Nosotros somos las abejas de lo invisible. Libamos incesantemente la miel de lo visible, para acumularlo en la gran colmena de oro de lo Invisible» (CB 279).

72. $\mathrm{CH} 7$.

73. $\mathrm{CH} 8$.

74. $\mathrm{CH} 9$. 
valor. Pero este planteamiento es un menosprecio y una renuncia a "la esencia del pensar" y en él se rechaza el ser como el centro del pensar.

La Lógica es la sanción de "esta interpretación" y es como el pez fuera del agua. Eso no quiere decir que la filosofía deba ser irracional. El rigor del pensamiento no está en su exactitud técnica sino «en que el decir permanece puramente en el elemento del ser» ${ }^{75}$. Es así como el pensar "oye y pertenece al ser".

Cuando la filosofía y el pensar pierden esta pertenencia, al ser, se convierte en pura técnica y violenta las cosas. Esto es la Modernidad. Así la vida privada ya no es la esencia humana, como "ser libre del hombre", sino un reducto de lo público, y eso pone al descubierto su triste esclavización a la pura publicidad. Aquí ya se puede ver por qué Sloterdijk recurre a Heidegger. Porque para librar al hombre del instrumentalismo y de la escandalera mediática hay que recogerse de nuevo y dialogar con el ser.

Si esto ya no fuera posible, la palabra, que está al servicio del ser, pierde todo su sentido y surge la dominación de la subjetividad por la publicidad. Así se produce la desecación y la esterilización del lenguaje que nos rehusa su esencia en cuanto casa del ser. Así es lenguaje instrumental. Pues el hombre, antes de hablar, debe "dejar que el ser hable". Entonces vuelve a la palabra "la preciosidad de su esencia" y el hombre encuentra su morada que le hace vivir en la propia "verdad del ser".

\section{2. El hombre y los humanismos}

Si ha de haber un humanismo este ha de ser humano y hacer más humano al hombre. Pero la humanidad del hombre descansa siempre en su esencia. Marx ve la esencia del hombre sólo en la cosa social. El cristianismo la pone en su ser de "hijo de Dios". Así huye de este mundo y se vuelve platonizante. En la época romana se hablaba del humanismo frente al mundo de los bárbaros que vive la virtud romana mediante la paideia griega. El hombre Renacentista también se pretende humano, y entonces la inhumano es «la pretendida barbarie de la escolástica gótica de la Edad Media»76.

75. CH 10. La verdad es la verdad del ser, y es «el sumirse extático del hombre existente en el desocultamiento del ser» (CB 72).

76. $\mathrm{CH} 16$. 
En todo caso, el humanismo casi siempre se viene a decir como "revivificación" del mundo del helenismo. Así ocurre también, en el siglo XVIII alemán, con Winckelmann, Goethe y Schiller. Hölderlin, por el contrario no acepta este humanismo pues pone la esencia del hombre muy fuera del helenismo. Para él, el hombre es vida en grande, es generosidad y es alma en el sentido de ánimo ${ }^{77}$.

Si el humanismo es lucha por la dignidad del hombre para que este sea libre, todo depende lo que se entienda por libertad y naturaleza. Así vemos que Marx y Sartre no van a la Antigüedad. Por su parte, el cristianismo busca la salvación del hombre. Los tres parecen tener una idea fija de naturaleza, de la historia y del principio del mundo que funda el ente y el todo.

Así: «Todo humanismo o se funda en una metafísica o se hace a sí mismo fundamento de una metafísica» ${ }^{78}$. $\mathrm{Y}$ toda determinación de la esencia del hombre que nos interpreta al ente sin preguntar por el ser es muy mala metafísica. Los citados humanismos se olvidan siempre del ser y nos presentan al hombre como "animal rationale". Esta teoría no es falsa pero olvida lo esencial. Ni la racionalidad ni la animalidad nos dan la esencia del hombre, y, con demasiada frecuencia, se cae en la animalidad.

\section{3. El hombre a la luz del ser.}

Toda mala metafísica se olvida de lo esencial, confunde lo que es la esencia y así falsifica todo, ya «que el hombre sólo se deja ser en su esencia en la que es solicitado por el ser»79. Sólo así, el hombre encuentra su esencia que

77. «"Alma" significa lo mismo que "ánimo" (Gemüt)(...). Animo es la fuente y el lugar (...) del equilibrio (Gleichmut) y de la pobreza (Armut), de la suavidad (Sanftmut) y de la nobleza de ánimo (Edelmut), de la gracia (Anmut) y del ánimo de sacrificio (Opfermut), de la magnanimidad (Grossmut) y de la longanimidad (Langmut). El ánimo, así percibido, lo llama Hölderlin "el alma". El hombre lleno de alma (...) es el ánimo elevado, el que tiene ánimo para asumir (zumuten) lo Supremo» (M. HEIDEGGER, Interpretaciones sobre la poesía de Hölderlin, Ariel, Barcelona 1983, 137). Por lo demás: «La belleza es la presencia del ser. El ser es lo verdadero del ente» (Ib., 147).

78. CH 17. «La metafísica sería en su esencia el misterio impensado -porque guardado del propio ser (...). La metafísica es una época de la historia del ser mismo. Pero en su esencia la metafísica es nihilismo» (CB 239).

79. CH 19. Según Zuckert, al ser nunca se le encuentra del todo, y con frecuencia se le olvida. Las cosas sólo son en cuanto se apropian el ser. El ser, que solamente acontece a través del ser humano (Dasein), ha "usado" y "poseído" al hombre. «Así pues, los seres humanos se hacen propiamente humanos, que quiere decir, inteligentes, seres en realidad, solamente al ser "tomados" en la "luz del Ser"» (C. H. ZUCKERT, Postmodern Platos 
define su existencia: «Yo llamo ex-sistencia del hombre al estar en la iluminación del ser. Sólo al hombre le es propio este modo de ser»80. Esta ec-sistencia entregada (al ser) es la sustancia del hombre. Condenarle al biologismo es un error garrafal, que no es nunca superable con un alma $u$ otro adorno espiritual. Pues incluso: «El cuerpo del hombre es algo esencialmente distinto de un organismo animal» 81 .

La esencia del hombre descansa en su ex-sistencia, en la "iluminación del ser". Para el medieval, la realidad de lo real es la objetividad, en Hegel la subjetividad absoluta y en Niezsche el eterno retorno, pero hoy la esencia del hombre se salda a la luz del ser. La planta y el animal se deben siempre a su ambiente, pero el hombre tiene un mundo que es la iluminación del ser, y vive en la verdad del ser.

La misma esencia del hombre no se determina, pues, ni desde el ser de la esencia ni desde el ser de la existencia sino "desde lo ec-stático del En-ser". Y ese En es "la iluminación del ser en el cuidado". La conferencia De la esencia de la verdad recuerda, con claridad, el gran olvido del ser que proviene de Platón.

En esa misma desgracia cae la frase de Sartre: "La existencia precede a la esencia" que es la frase de Platón, ahora puesta al revés. «Pero el revés de una frase metafísica sigue siendo una frase metafísica (...) Tanto él como esta frase se mantienen con la metafísica en el olvido de la verdad del ser» ${ }^{82}$. En ese olvido del ser cayó todo el Occidente. Y con todo eso, Ser y Tiempo, no tiene nada que ver.

\section{4. El ser como patria del hombre}

$\mathrm{Al}$ hombre le importa el ser y el "ser solicita y recurre al hombre". De eso se olvidó el humanismo y por eso es antihumano. Y rebaja al ser humano, tanto si lo subjetiviza como si lo objetiviza. Así no se cuida al ser sino que se le pervierte. El hombre se cuida el ser, su ser y los otros seres, pues esa es la misión del hombre: «El hombre es el pastor del ser» ${ }^{83}$.

\footnotetext{
Nietzsche, Heidegger, Gadamer, Strauss, Derrida, Univ. of Chicago Press. Chicago 1996, 61). 80. $\mathrm{CH} 20$.

81. CH 20.

82. CH 25. «El olvido del ser es el olvido de la diferencia entre el ser y lo ente» (CB 329).

83. $\mathrm{CH} 28$.
} 
¿Pero qué cosa es el ser?. "El ser es lo más cercano". Y la cercanía misma esa es la verdad del ser. No es Dios ni ángel ni bestia ni máquina ni animal ni tampoco obra de arte. El ser es como la luz que a todo ser ilumina. «Pues en la luz del ser está ya toda salida desde el ente y toda vuelta a él» ${ }^{84}$. Sólo así es posible la autenticidad y la comunicación, "la sobria cercanía de un dominar no impositivo" y de un lenguaje abierto que es la propia "casa del ser", donde el hombre se hace hombre en la propia "verdad del ser".

En este preciso sentido, el existencialismo no es un humanismo. Pues Sartre se pone en un plan en el que sólo hay hombres. Pero, para Heidegger, "el ser y el plan son lo mismo". Pues el ser es el que se da y así vemos que se da el ser y lo que da "es el ser mismo". «El da nombra la donante esencia del ser, guardadora de su verdad. El darse en lo abierto con este mismo es el ser mismo» ${ }^{85}$. Así hay una historia del ser que es la historia en que el ser se da y ese darse es su destino.

Sólo, en cuanto el ser se apropia se entrega en propiedad al hombre, pero el ser no es, para nada, mero "producto del hombre". Pues el ser es "lo transcendente por antonomasia", pues es "la iluminación misma" y está "más allá de todo ente". El ser se aparece al hombre en "el proyecto ec-stático", pero él no es el que crea el ser86.

El ser es la patria del hombre y de él recibe su historia: «La patria de este morar histórico es la cercanía al ser» ${ }^{87}$. Sólo en esa cercanía sabemos lo que es el día de gracia y también la ausencia de Dios. Pero el día de la gracia sólo llega cuando ya "se ha alumbrado el ser mismo", y sólo así se supera la apatridad en la que yerran los hombres y "la esencia misma del hombre". Esa

84. $\mathrm{CH} 29$.

85. CH 32. Para J. L. Marion, la estructura fundamental de la evidencia es la "donación". Este tema que comienza en Husserl, lo continúan Heidegger y C. Bruaire. «Tal es el sentido de Donation et réduction: mostrar cómo la esencia originaria (...), es un don "más grande" que lo que deseamos (...). De ahí la admiración y la alabanza, que son las virtudes filosóficas por excelencia, ante lo que es (...). "El hombre (...) no recibe como tal el don sino acogiendo el acto de dar, es decir por repetición dándose él mismo. Recibir el don y darlo (...), en una simple posesión. Recibir y dar se consuman pues, en el mismo acto"» (J. L. MARION, L'idole et la distance, Grasset, Paris 1977, 212, en P. HILBERT, Algunos pensadores contemporáneos de lengua francesa. Univ. Iberoamerica, México 1996, 120).

86. «La vida corriente del hombre actual es la vida corriente de la autoimposición sobre el mercado desprotegido de los cambistas. El traspaso de la balanza al ángel es, por contra, lo inhabitual» (CB 284). El ángel es lo que salva al ente. La esencia de lo humano es, frente la autoimposición, la disponibilidad. Del mismo modo el poeta sigue la huella sagrada: «Su canción, por encima de la tierra salva y consagra. Su canto celebra lo intacto de la esfera del ser» (CB 288).

87. CH 37. 
apatridad descansa en "el abandono del ser del ente", es el signo de su olvido y de su amplia confusión, incluso como ente abarcante.

\section{5. El olvido del ser, la técnica y el humanismo}

Así, el ser "queda oculto". Y lo que Marx y Hegel pensaban como "el extrañamiento del hombre" hunde sus raíces en "la apatridad del hombre moderno", que se ha olvidado a Hölderlin. En esta visión de la historia supera Marx a los otros. El ha visto el "extrañamiento" que no han logrado intuir Husserl ni el existencialismo. Por cierto, que el materialismo no consiste en que todo sea materia, sino en que toda la realidad aparece como mero material de trabajo. Esto ya se encuentra en Hegel pero se afirma en la técnica.

La esencia del materialismo, se oculta en la esencia técnica. La técnica es olvido del ser ${ }^{88}$. Eso es el americanismo y eso fue el comunismo. La mayor grandeza de Europa ha sido siempre el pensar, pero ahora se halla rendida o por lo menos sitiada. Es bueno reaccionar e intentar resucitar, porque: «El hombre no es el señor del ente. El hombre es el pastor del ser (...) El hombre es el vecino del ser» 89 .

He aquí el verdadero humanismo, "que piensa la humanidad del hombre desde la vecindad del ser". Y este reino del ser, no es un callejón sin salida, como a veces se ha dicho, sino el reino franco donde "la libertad guarda su esencia", pues el hombre es peregrino "a la vecindad del ser". Sólo así lo humano y la humanitas será la esencia del hombre en cuanto pastor del ser.

Esto no es oponerse al humanismo, a los valores, a Dios, ni a la lógica sino ver el nihilismo. Son los otros humanismos los que se muestran inhumanos por sus cosificaciones. Cosificar los valores empeora los problemas, sobre todo cuando lo que se cosifica es lo más sublime, como suele hacerse con Dios que se queda transformado en una "causa primera" 90.

88. La era de la técnica es el invierno infinito: «El mundo se torna sin salvación, pierde todo carácter sagrado. De este modo, no sólo lo sagrado permanece oculto como rastro que lleva hacia la divinidad, sino que hasta esa huella hacia lo sagrado (...) parece haber sido borrada (...) El peligro consiste en esa amenaza que atañe la esencia del hombre en su relación con el propio ser y no en peligros casuales. Este peligro es el peligro. Se esconde de todo ente en el abismo. A fin de que el peligro sea visto y mostrado, tiene que haber esos mortales que son capaces de alcanzar antes el abismo» (CB 266).

$89 \mathrm{CH} 41$.

90 «Si la metafísica piensa lo ente en su ser como voluntad de poder, piensa necesariamente lo ente como instaurador de valores» (...) Y así se rebaja el ser a nivel antropológico: «Al final el ser ha caído en la metafísica al nivel de valor. Ahí se demuestra que el ser 
También se cosifica al mundo, cuando se hace de él una cosa, pues el mundo no es "un reino de los entes, sino la apertura al ser". Sólo así el hombre emerge en la "apertura del ser": «"Mundo" es la iluminación del ser en la que el hombre emerge desde su esencia arrojada» 91 . El ser-en-el-mundo nombra la esencia de la ec-sistencia humana. Y, es preciso advertir que ahí aún no se decide si hay también un más allá o todo queda aquí mismo. Lo mismo debe decirse de "la existencia de Dios", y por tanto del ateísmo...

Heidegger ya lo había advertido en De la esencia del fundamento, pero es mucho lo que se "peca además contra el cuidado del leer". Su filosofía no se decide ni "por la existencia de Dios ni contra ella". Y eso tiene que ser así porque: «Sólo desde la verdad del ser deja pensarse la esencia de la gracia. Sólo desde la esencia de la gracia está por pensar la esencia de la divinidad. Sólo en la iluminación de la esencia de la divinidad puede ser pensado y dicho lo que ha de nombrar la palabra Dios» ${ }^{92}$.

Sin esta apertura al ser, el hombre actual carece de espacio apropiado para preguntar por Dios, pues la dimensión de la gracia está previamente cerrada por la fuerza de las cosas: «Tal vez consiste lo característico de esta época en el cierre de la dimensión de la gracia. Tal vez es ésta la única desgracia» ${ }^{93}$.

Esto tampoco supone afirmar ya el teísmo, como el pensar el misterio no es irse por las nubes sino que más bien desciende "a la cercanía de lo más cercano". Por eso el biologismo, el pragmatismo y el animalismo es puro enceguecimiento. «Pensar la verdad del ser quiere decir a la vez: pensar la humanitas del homo humanus» ${ }^{94}$. Y así darle fundamento ${ }^{95}$.

no es admitido como ser» (...). Y esto es el nihilismo. El pensar según valores es mortal «porque no deja en absoluto que el propio ser haga su aparición, esto es, que alcance la viveza de su esencia. El pensar según valores impide ya de antemano incluso que el propio ser se presente en su verdad» (...) «En ningún lugar nos sale al encuentro un pensar que piense la verdad del ser mismo y, por tanto, la propia verdad en cuanto ser» (...) «La historia del ser comienza, y además necesariamente, con el olvido del ser» (CB 215.233.237).

91. $\mathrm{CH} 51$.

92. $\mathrm{CH} 52$.

93. $\mathrm{CH} 53$.

94. CH 54.

95. «El poner la obra a la verdad hace que se abra bruscamente lo inseguro $\mathrm{y}$, al mismo tiempo, le da la vuelta a lo seguro y todo lo que pasa por tal. La verdad que se abre en la obra de arte no puede demostrarse ni derivarse a partir de lo que se admitía hasta ahora. La obra rebate la exclusividad de la realidad efectiva de lo admitido hasta ahora (...). La fundación es algo que viene dado por añadidura, un don» (CB 65). 


\section{5. 1. Hombre, ética y humanismo}

Para Heidegger, la desorientación actual, notoria o más bien negada, no se ha de arreglar sin más con escribir una Etica. La única garantía, de las cosas y los hombres, no es otra que el mismo ser. Pensar a la luz del ser, es la ética suprema. Así, la condición propia del hombre es escuchar a su daimón, pues el hombre, en cuanto es hombre, mora "en la cercanía de Dios", como lo había dicho Heráclito. Los curiosos quieren ver la vida del pensador en toda profundidad, pero él tiene que vivir en la realidad cotidiana, familiar y consabida, en "toda la estrechez de su vida", pues "también aquí se presentan los dioses".

Esa realidad cotidiana es el lugar de la apertura para el hombre y de "la presentación de Dios". Y este pensar no es teórico ni práctico sino que es el pensar del ser. Ni tiene eficacia alguna sino que se basta en su esencia, pues es más libre que todos porque "deja ser al ser". El pensar no hace la casa al ser sino que conduce la ec-sistencia histórica, la humanidad del hombre humano "al reino de la aurora de las gracia".

El ser es más que todo ente. El hombre es oyente del ser que sorprende en "lo sencillo" más allá de la pragmática. Eso exige rigor en la reflexión, solícito cuidado en el decir y sobriedad en las palabras. Ese ser nos anonada para llamarnos a ser y a toda su "benevolencia". «Lo anonadador en el ser es la esencia de lo que yo llama la nada. Por eso, porque la "nada" piensa el ser, piensa el pensar la nada»96. El nomos dispone al hombre en el ser, pues el ser es el que "protege al hombre", que así adviene al lenguaje, para que el hombre se salve, y no se vuelva "psicótico" como diría Sloterdikj. Por lo demás: «El lenguaje es el lenguaje del ser como las nubes son las nubes del cielo» ${ }^{97}$. Del mismo modo el pensar, que no es ciencia definitiva sino amor a la sabiduría, en su pobreza provisoria y sencilla, es también pensar del ser que va labrando nuestra tierra como el surco del labriego.

96. $\mathrm{CH} 63$.

97. $\mathrm{CH} 68$. 


\section{Conclusión}

Hoy día la obra de Sloterdijk está muy consolidada y no se puede soslayar, ni centrarla en una conferencia, por muy llamativa que sea. Su Crítica de la razón cínica es un escrito esencial que con su ataque al nazismo y al socialismo real sentencia, a las viejas guardias, de modo definitivo. Sólo así se entra de lleno en la posmodernidad. Esa obra cierra una época y pide nuevos horizontes que ese autor ya ha explorado en Normas para el parque humano.

Como en toda exploración, puede haber siempre accidentes, pero si se lee el texto, que se ha hecho tan famoso, no existe ninguna razón para empujar a su autor al profundo del abismo, por mucho que hoy todo accidente tenga gran publicidad y venda muchos periódicos. De sus críticos se puede afirmar lo que ya Heidegger dijo: que es mucho lo que se "peca además contra el cuidado del leer"

La obra de Habermas, y de toda la escuela de Frankfurt, también debemos decir que ha sido muy benemérita. Generaciones enteras se han formado y han vivido una ilusión de futuro con su crítica al intrumentalismo y al positivismo frío. Eso no se puede negar y tampoco ensombrecer. Pero estamos en nueva época, y antes de que cayera el muro triste de Berlín, ya se iba a derrumbar la ideología que lo levantó y, bien que mal, lo sostenía a base de violencia. La Nueva Filosofía y el Pensamiento Posmoderno, en el Arte, en la Literatura, en la Filosofía, habían reclamado, con insistencia, la desaparición final de la violencia moderna.

En esta línea de acción, y de pensamiento, la filosofía de Sloterdijk es una apisonadora que no deja opción alguna de vuelta al viejo sistema: vestigia nulla retrorsum, proclamaban ya los clásicos. Si Habermas y su entorno, se niegan a caminar mirando al nuevo futuro del fin de la violencia, Sloterdijk, P. Bruckner, A. Finkielkraut, G. Vattimo, Primo Levy y tantos otros se convertirán para ellos en una gran pesadilla. Nunca se debe olvidar que la mayor gloria del pensamiento débil o posmoderno ha sido, sin duda, volver a priorizar de nuevo la fuerza de la razón frente a la razón de la fuerza y de la "coerción".

En todo este proceso, Heidegger, el viejo brujo, mantiene fuerte su plaza, su teoría del ser, que está en el claro del bosque y también vive en nosotros, sigue seduciendo a muchos porque nos revela al hombre y nos invita también a preguntar por el mundo, nos cuestiona nuestra vida y toda la realidad. No es nada raro, por tanto, que Sloterdijk recurra a él, de nuevo, para explorar el futuro y utilice sus escritos en la nueva singladura.

Lo importante en este escándalo, como en toda discusión, es que nos

pueda ayudar a pensar nuestros problemas: el sentido de la vida, el encuentro 
con los otros, la solidaridad global y el diálogo entre los pueblos. Pues como decía Camus: en realidad, solamente hay un problema filosófico y este no es otro, en verdad, que el del sufrimiento humano. O como lo diría Sloterdijk: «El moderno consenso ecológico del dolor - que la gran mayoría no deba sufrir eternamente por una minoría- es el mínimo común denominador de todas las posiciones dentro del paisaje fragmentado de la modernidad» 98 .

DOMINGo NATAL Estudio Teológico Agustiniano

Valladolid

98. PE 156. 